\title{
Integrating Customers in Product Innovation: Lessons from Industrial Development Contractors and In-House Contractors in Rapidly Changing Customer Markets
}

\author{
Patricia Sandmeier, Pamela D. Morrison and \\ Oliver Gassmann
}

Successful product innovation has increasingly been recognized as an outcome of integrating customers into the new product development (NPD) process. In this paper, we explore customer integration by investigating the continual consideration of customer contributions throughout the product innovation process. Through a comparison of the customer integration practices by development contractors with those of in-house developers, we find that the iterative and adaptive innovation process structures of the development contractors facilitate the realization of the full customer contribution potential throughout the product innovation process. We also find additional support for the incorporation of open innovation into an organization's NPD activities. Our findings are based on in-depth case studies of the NPD activities of in-house developers and product development contractors.

\section{Introduction}

$\mathrm{T}_{\mathrm{on}}^{\mathrm{h}}$ he positive impact of customer integration on product innovations has long been acknowledged. Empirical research shows that the integration of customer contributions in new product development (NPD) leads to a higher degree of product newness, reduced innovation risks and more precision in resource spending (Gupta, Raj \& Wilemon, 1986; Kohli \& Jaworski, 1990; Bacon et al., 1994; Millson \& Wilemon, 2002; Brockhoff, 2003; Callahan \& Lasry, 2004). In particular, the value of lead users has been demonstrated by various researchers: the value of product innovation increases when users bring their specialized knowledge of needs, preferences and solutions to NPD, leading to new products that provide true value to customers (von Hippel, 1976, 1977, 1978, 1988; Herstatt \& von Hippel, 1992; Lilien et al., 2002; Morrison, Roberts \& Midgley, 2004; Lüthje, Herstatt \& von Hippel, 2005).
Most work in this field focuses on approaches in which customer integration stands for a better understanding of customers' initial product requirements. These approaches include 'market orientation' (Kohli \& Jaworski, 1990; Atuahene-Gima, 1996), the 'voice of the customer' (Griffin \& Hauser, 1993), the 'virtual customer' (Paustian, 2001; Dahan \& Hauser, 2002), 'customer driven innovation' (Billington, 1998), or 'consumers as co-developers' (Jeppesen \& Molin, 2003). With this understanding, the customers' contributions can be brought into R\&D directly or through the marketing department to develop new products that fit customers' real needs and wishes (von Hippel, 1978; Griffin \& Page, 1996; Berry \& Parasuraman, 1997; Dahan \& Hauser, 2002; von Hippel \& Katz, 2002).

In this paper, we explore customer integration by investigating the continual consideration of customer contributions throughout the product innovation process. We compare the practices of development contractors - i.e., professional technical service firms that 
innovate on a contract basis - with that of in-house developers. The technical service firms develop new products with a very high success rate but with different organizational structures and processes compared to traditional in-house developers. We chose this comparison in order to reveal the factors on which the development contractors' success is based. We find that their iterative and adaptive innovation process structures facilitate the realization of the full customer contribution throughout the product innovation process.

The question of how customers can contribute to product innovation activities and how and where their contribution can be built into the NPD process to take advantage of the full customer integration potential has not previously been addressed. We contribute to close a theoretical gap by showing that a continuous consideration of customer contributions throughout the product innovation process requires a recurring pattern of accessing, releasing and absorbing customer contributions. This insight helps answer how innovation capabilities from outside the $R \& D$ department can be capitalized.

The paper is structured as follows: Section 2 provides the theoretical background from existing literature; Section 3 develops the framework which guides the comparison between the practices applied by development contractors with those of in-house developers; Section 4 introduces our research methodology; Section 5 presents the results from the case study comparison, leading to four research propositions; and in Section 6 we discuss the implications of our research findings. We conclude with limitations and recommendations for further critical and practical work.

\section{Research Background}

In environments where requirements can be highly uncertain, changing customer needs have to be faced for the development of industrial products. Experimental NPD methodologies tolerating these changes were found to be the only ones capable of bringing out innovative new products in the required period of time (Lynn, Morone \& Paulson, 1996). Since existing change-oriented approaches focus on the ability to learn and share information quickly (Zahay, Griffin \& Fredericks, 2004), we focus on organizational learning theory to guide us as a theoretical starting point.

Organizational learning is defined as the process of improving actions through better knowledge and understanding (Fiol \& Lyles, 1985). Applying this definition to the research terrain of customer integration, learning from customers throughout the development of new products implies that the company learns about its market through a series of sequential information processing activities undertaken with its customers (Kok, Hillebrand \& Biemans, 2003). Learning about markets for new products can be understood as an organizational learning process that involves the acquisition, dissemination and utilization of information (Fiol \& Lyles, 1985; Imai, Ikujiro \& Takeuchi, 1985; Huber, 1991; March, 1991). First, acquiring market information consists of the collection of information about the needs and behaviour of customers. Some of this information can be obtained from data banks and the results of past actions, whereas some needs to be collected anew through quantitative (e.g., market surveys) or qualitative (e.g., customer visits) methods (Adams, Day \& Dougherty, 1998). Second, market information has to be disseminated across functions, phases of the innovation process, geographic boundaries and organization levels (Adams, Day \& Dougherty, 1998). Third, using market information occurs in the process of learning about the market for decision making, the implementation of decisions, or evaluations of a new product (Menon \& Varadarajan, 1992).

We use the constructs from learning theory - acquisition, dissemination and utilization to structure a literature review on integrating customers into NPD.

\section{Acquisition of Knowledge}

To profit from customer know-how, this know-how first has to be acquired. Literature on integrating customers emphasizes the choice of the right partner from whom the required information can be obtained as a core aspect of interacting with customers (Gruner \& Homburg, 2000). Biemans (1992) states that the identity of the customers employed typically varies with the extent and intensity to which the customer is involved, as it does with the stage of the NPD process.

Gruner and Homburg (2000) identified three different characteristics of valuable co-operation partners for NPD: financial attractiveness, closeness of customers and the lead user characteristics. First, customers' financial attractiveness relates to their representativeness of the target market and their reputation within that market (Ganesan, 1994). The second characteristic is the closeness of the relationship between the developing company and the customer, including the level of interaction outside the respective innovation project and the duration of the business relationship (Doney \& Cannon, 1997). Lead users, 
as defined by von Hippel (1986, 1988), combine two characteristics: they expect attractive innovation-related benefits from a solution to their needs and so are motivated to innovate, and they experience needs for a given innovation earlier than the majority of the target market. Von Hippel (1986) proposed and Urban and von Hippel (1988) tested the proposition that idea-generation studies can learn from lead users, both within and well beyond intended target markets - lead users found outside the target market often encounter even more extreme conditions on a trend relevant to that target market. Their positive impact on product innovations has since been demonstrated by several studies (Herstatt \& von Hippel, 1992; Lilien et al., 2002; Lüthje \& Herstatt, 2004).

\section{Dissemination of Knowledge}

The imperative of opening up the NPD process has been discussed within open innovation research (Chesbrough, 2003; Gassmann, 2006). This openness should enable organizations to react to significant changes which occur in rapidly changing markets in both customer needs and technological potentials during the NPD process. This can be done through experimentation by providing toolkits (von Hippel \& Katz, 2002) or early versions of prototypes of the product under development to the customer for feedback on a regular basis (Thomke, 1998, 2001).

Thomke's work points out the relevance of prototypes - or, more generally - the visualization media for transferring the project to the customer site and to release customers' contributions. Visualization through paper concepts, mock-ups, rapid prototyping and computer aided design can help in information sharing and building consensus over the course of a development project (Terwiesch \& Loch, 2004; Veryzer \& Borja de Mozota, 2005). Physical representation of the product under development at different points of the NPD process help to create a common understanding of development issues which may arise according to the different vocabularies and environments the involved stakeholders come from.

\section{Utilization of Knowledge}

The best possibility to utilize customer contributions is generally seen in the early phases of the product innovation process, the so-called innovation front-end or product definition phase (Murphy \& Kumar, 1997; Kim \& Wilemon, 2002). Approaches such as the StageGate $^{\mathrm{TM}}$ model of innovation (Cooper \& Kleinschmidt, 1986; Cooper, 1994) can be very useful; however, they have not completely captured the impact of dynamic user-oriented activity throughout the NPD process (Veryzer \& Borja de Mozota, 2005). They do not provide sufficient flexibility to respond to changing information during a development project and therefore are not able to 'hit a moving target' in conditions of high-velocity industries (MacCormack, Verganti \& Iansiti, 2001).

One way to realize flexible NPD is through frequent iterations without forcing early development in a wrong direction or restraining the customers to their initial inputs (Griffin \& Hauser, 1993). Multiple explorative development iterations, complemented by extensive testing, and frequent milestones help to overcome the randomness through missing technological and customer information (Eisenhardt \& Tabrizi, 1995; Terwiesch \& Loch, 2004). Generally, development based on an iterative process further suggests a more realtime, hands-on approach to fast product development, especially for uncertain products.

Lynn, Morone and Paulson (1996) demonstrated that the realization of a process which is able to continually consider new customer input requires probing, testing and learning. This implies a continuous interplay between developers and customers of acquiring, disseminating, utilizing, and re-acquiring new customer contributions.

\section{Analogies from Successful Practices: Extreme Programming (XP)}

In the search for analogies to flexible product innovation approaches that successfully manage the intersection of customers and $R \& D$, a solution emerges from Extreme Programming $(\mathrm{XP})$ in the software engineering context. In XP's product development methodology, the product innovation process is organized to ensure a continual flow of highquality contributions from customers to the development activities surrounding a new product. While this approach and the underlying agile project management practices have received a high acceptance among software engineers, the concept is less known in the 'hardware world' of new product creation. We introduce the Extreme Programming methodology in the following as it will be used in developing a framework for the investigation of explorative (iterative) practices on integrating customers into the NPD process.

Extreme programming is one of the most popular methods of agile software development which refers to the low-overhead methodologies developed for environments with rapidly changing requirements. These methodologies minimize risk by ensuring that soft- 
ware engineers focus on smaller units of work (Acebal \& Cueva Lovelle, 2002). In agile software development, collaboration with the customer throughout the entire NPD process is considered much more important than defining a development contract in advance, and the overall goal is to provide a benefit for the customer as soon as possible (Dornberger \& Habegger, 2004).

$\mathrm{XP}$ is shaped by the incremental, iterative development of sequenced small release (prototype) cycles, according to customers' contributions. This procedure minimizes the length of the feedback cycles and helps reveal new customer needs which were not previously known by the customer himself. Empirical research on decision making shows that customers are frequently unaware of their problem situations, underlying preferences, problems and choice criteria (Simonson, 1993; Mullins \& Sutherland, 1998). Within the releases, most design activities take place on the fly and incrementally, starting with the 'simplest solution that could possibly work' and only then adding complexity.

In traditional software development methods, such as the waterfall model for example, first an extensive analysis regarding all product requirements and project time and scope are performed and only after this first stage are the contributions from the customer accessed and released, by translating the requirements into planned product specifications.

By contrast, $\mathrm{XP}^{\prime} \mathrm{s}$ iterative processes have smaller steps and several iterations with working releases in between, where customer contributions are repeatedly accessed, released and absorbed: access refers to developers interacting with customers to obtain know-how, release refers to making the customers' knowhow visible to the developer, often in the form of prototypes, and absorption refers to the conversion and internalization of selected customer contributions into the specific innovation project. These terms are equivalent to the acquisition, dissemination and utilization stages in Learning Theory. The customer's contributions are implemented continuously with the customer watching the new product evolve according to his uncovered and released needs and then making further contributions (Dornberger \& Habegger, 2004).

Since in XP the customer receives a physical product element with each release, feedback is provided not from his ability of imagination, but rather the presence of intermediary results enables him to become aware of his unanswered needs and requirements. As a result, the customer contributes to determining the new product's scope and functionality at each stage, instead of being contacted only for relevance verification and design adjustment, as is the case in traditional software development and in most cases of industrial NPD.

While there are many benefits to the XP method, its applicability for NPD is limited to certain types of customer needs. That is, $\mathrm{XP}$ can be applied only to $R \& D$ projects that do not consist of complex technical constructs but instead focus on developments that occur close to the interface with the user of the system. An example from software development is in the elevator industry where XP is not used to develop the technology for a new elevator concept in which the basic needs still consist of going up and down in a building and opening the doors, but it is successfully applied to develop new functionalities such as floor access control by which the user is directly affected.

\section{Reference Framework for the Continual Integration of Customers in Industrial NPD}

The exploration of $\mathrm{XP}$ points out the relevance of a differentiated consideration of accessing customer contributions, customer contribution release and customer contribution absorption. This also supports a further consideration of the three elements in organizational learning theory where learning about markets for new products can be understood as a process of acquisition, dissemination and utilization of information (see Section 2).

Following the structure of customer contribution access, release and absorption, we subsequently compare XP's key elements of integrating customers with the existing customer integration literature. The presented result is a set of constructs that serve as a reference framework which guided our explorative investigation of the case studies.

\section{Access to Customer Contributions}

$\mathrm{XP}$ succeeds in discovering customer needs and values by collecting customer contributions at the customer's site and getting a lowfunctionality version of the product into customers' hands at the earliest opportunity. Therefore, closeness is crucial in $\mathrm{XP}$, because every finished release gets presented to the customer in the form of a prototype. This procedure may be viewed as a method for rapidly building and disseminating both explicit and implicit market and technology know-how among members of the development team and 
the customer, which advances the project. Furthermore, the customer has a fixed role in the product development team, which also supports the closeness between developers and the customer. In the literature, the closeness factor has been mentioned as a means to build and maintain trust (Anderson \& Narus, 1990; Morgan \& Hunt, 1994; Buttle, 1996; Hutt \& Stafford, 2000; Rindfleisch \& Moorman, 2001). Therefore, developers and the customer should interact as closely as possible and in the case of 'sticky' information possibly even transfer the development project to the customer site (von Hippel, 1994).

The literature on customer integration into product innovation further emphasizes the characteristics of the customer involved, particularly in research on the lead user concept (Herstatt \& von Hippel, 1992; Lilien et al., 2002; Morrison, Roberts \& Midgley, 2004). Other authors, such as Gruner and Homburg (2000), showed that in addition to lead user characteristics, criteria such as the representativeness of customers for the target market and their reputation in those markets, as well as the intensity of the interaction between the manufacturer and customer beyond a particular project, can significantly discriminate between better or worse performing products.

Martin and colleagues (Martin et al., 2003, 2004) emphasize that identifying the individual within the customer organization with the ability to fulfill the customer role in the XP process represents a success factor. Therefore, the specific person who contributes to the new product under development is an important factor, because he or she determines the role played by the customer.

\section{Release of Customer Contributions}

Research on experimentation modes has highlighted the role of testing and experimentation during the product innovation process (Simon, 1969; Allen, 1977; Wheelwright \& Clark, 1992; Iansiti, 1998; Thomke, 1998). Boehm, Gray and Seewaldt (1984) found that a prototyping process, which allows for changes late in the design process according to new know-how from and about customers, resulted in products that were not only judged superior from a customer perspective but were also developed with fewer resources.

First, $\mathrm{XP}^{\prime} \mathrm{s}$ multiple releases (comparable to prototypes) help overcome the customer's design uncertainty and eliminate potential $e x$ post regrets. Second, the increased number of releases provides the customer with more options from which to choose and thus leads to higher expected design quality, as has been shown by Terwiesch and Loch (2004) in a pro- totyping context. Furthermore, the releases help reduce the customer's uncertainty about their own preferences and insecurity about the producer's ability to meet their specific needs.

\section{Absorption of Customer Contributions}

The striking element in XP's product development process is the planning activity, which is reduced to a minimum for each release and seems absent in terms of the overall project. In the $\mathrm{XP}$ process, the customer contributes to the planning process through regular feedback after every release, which allows more precise estimations of the resources required. These improved estimations reduce the risk that relevant functionalities might not be considered. Another customer contribution comes from the evaluation of the value of each user story, so that the functionalities may be prioritized according to their relevance.

Consequently, explanations of $\mathrm{XP}^{\prime}$ 's process can be found in the research field of disciplined problem solving (Imai, Ikujiro \& Takeuchi, 1985; Quinn, 1985) rather than in a stream pertaining to rational planning (Myers \& Marquis, 1969), such as Cooper's Stage-Gate ${ }^{\mathrm{TM}}$ process (Cooper, 1990, 1994, 2001). Delving into the perspective of disciplined problem solving, an explanation for the profitability of XP's process cycles can be found in the loosetight concept developed by Wilson (1966) and Albers and Eggers (1991). Within each XP release, in which chaotic trial-and-error development is allowed, engineers can deploy their full creativity, introduce new ideas, and focus on developments that are technically possible. However, the procedure of collecting customer feedback occurs with a tight degree of organization.

Therefore, developing a new product with $\mathrm{XP}$ does not require control over the exact course of a project in either the early or in the late development phases. Instead, only some activities are fixed, and developers can make decisions over the course of their sequence and adoption, depending on the specific situation and variables (Dornberger \& Habegger, 2004).

\section{Further Elements Relevant for the Reference Framework}

The foundation of $\mathrm{XP}^{\prime}$ s product development process is provided by short, highly efficient development cycles of accessing, releasing and absorbing customer contributions. Customers assess the intermediary project results continuously and enrich them with their feedback. This continuous interplay between 
developers and customers has been addressed in the literature by Lynn, Morone and Paulson's (1996) probe-and-learn cycles. They state that repeating the probing and learning helps build new know-how, which leads to a superior new product that has been optimized in terms of technical feasibility and fit with customer needs. The success of such approaches is seen in the increased likelihood of improved project profitability through continuous guidance of the development process by customer requirements and through frequent cost and benefit control which has also been discussed from the perspective of total quality management (TQM) (Kaulio, 1998). These advantages exceed the costs arising from the provision of multiple prototypes, and the number of development projects that lead to failures in the market can be reduced significantly (Acebal \& Cueva Lovelle, 2002).

In the following, we use the above discussed constructs as a benchmark, comparing our data of in-house developers and development contractors against the model using analytic induction (Yin, 1994).

\section{Research Methodology}

Due to the inductive nature of exploring iterative customer integration in industrial NPD we chose a qualitative case study approach to gain a thorough understanding of the system (Yin, 1994). We studied several cases in detail to gain an in-depth understanding of their natural setting, complexity and context (cf. Punch, 1998).

The research consisted of three phases. In the first phase a literature analysis was conducted to explore the existing body of knowledge on product innovation processes and customer integration practices. In parallel, the theoretical insights were validated in expert workshops and contracted research projects with industrial goods developers in Northern Europe in order to find inconsistencies and identify further research requirements which are most relevant. This literature analysis and practical reflection led to the theoretical base which was introduced in Section 2.

The second phase developed a framework (Section 3) containing the identified aspects in the context of an extreme example of experimental NPD, using the XP method from software engineering as a foundation. NPD with the XP method is extreme because innovative customer know-how is extensively utilized throughout the entire NPD process. Because little is known about the XP method in innovation research (the available literature is limited to some practical guidelines), inter- views were conducted with experienced software engineers. These software engineers work in software departments of the companies considered in the first phase or software institutions that specialize in the application of XP (Object XP, Lifeware, FH Zentralschweiz).

In the third phase the framework developed with XP was applied to conduct the comparison between in-house developers and development contractors. Contractors (professional technical service firms) develop product innovations with clients on a project basis - and therefore with a different model of industrial product development than the in-house developers. Both traditional in-house developers and development contractors are included in the research in order to cover a broad spectrum of industrial NPD settings and thus allow us to investigate the successful application possibilities of explorative iterative practices.

\section{Sample Selection}

To gain insight we carried out an in-depth analysis of selected projects and companies (Stake, 1988; Eisenhardt, 1989; Yin, 1994). In order to allow for a comparison within the different development models, the investigation took place at the level of specific NPD projects and their practices. We selected four companies in which the product innovation process could be studied comprehensively. The criteria for selecting firms were based on their potential for learning. We selected two in-house developers: Hilti (Liechtenstein) and Buechi Labortechnik (Switzerland) and two development contractors: IDEO (Germany) and Tribecraft (Switzerland). All firms cover the complete spectrum from low- to high-tech. Hilti was chosen due to its reputation as a company that successfully practices a leaduser approach. Buechi excels in its closeness to customers (distributors) and users throughout its product innovation process. As a result of the authors' close collaborations with this company in previous research projects, we could ensure access to sensitive customer information and a broad data validation process. IDEO - broadly investigated in NPD literature - and Tribecraft engaged in very tight collaborations with their customers and have developed product innovations that stand out in terms of their degree of novelty and superior design. An overview of these four companies is presented in Table 1.

\section{Data Collection}

In all phases, data were collected through personal, face-to-face interviews lasting between 


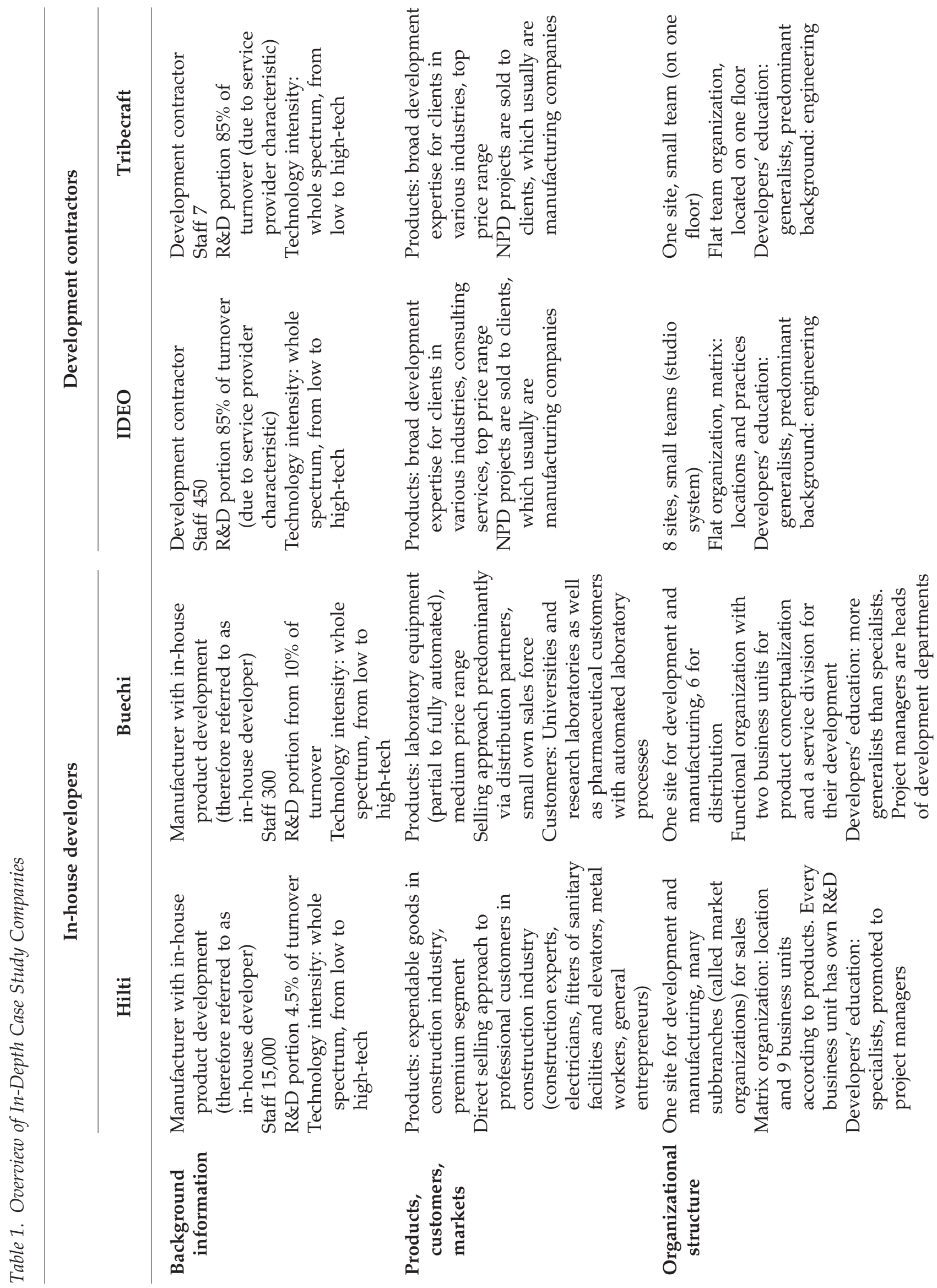




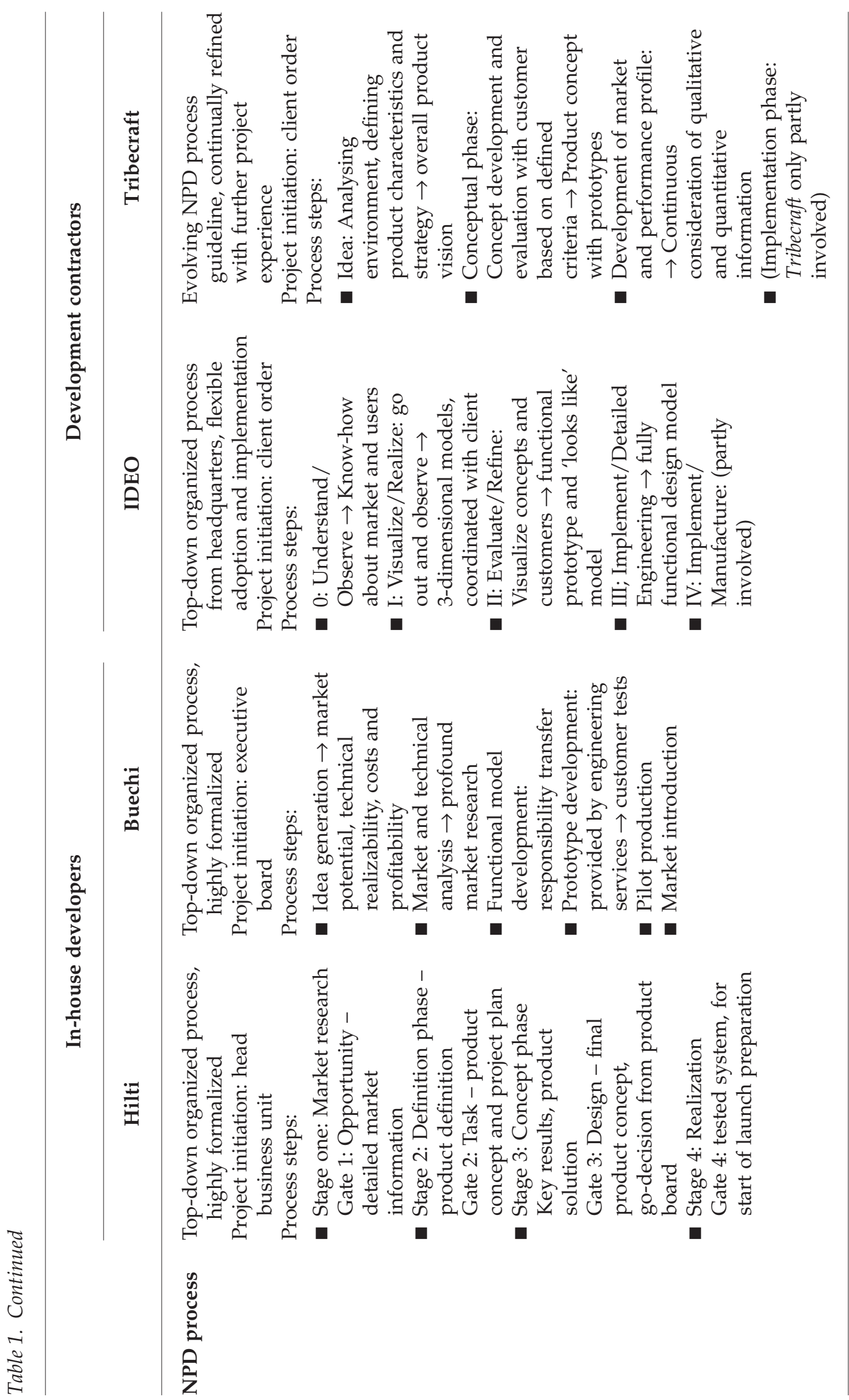


30 and 90 minutes with chief technology officers, R\&D directors, R\&D project managers, developers, engineers and product managers. A total of 26 interview hours with 25 people were recorded in phase one; 13 interview hours with 5 people in phase two; and in phase three, 42 interview hours were recorded with 5 people from Hilti, 7 from Buechi, 2 from IDEO and 2 from Tribecraft. Participants were selected so that different levels of customer contact and product innovation responsibilities were represented. Most informants had personally participated in customer integration activities, and they were asked to focus on a specific project from the preceding 18 months. An interview guideline was used to maintain the coherence of the data collection throughout the research phases. Interview data were augmented by desk research, namely, analyses of company publications, annual reports, internet web pages, project memos and internal presentations. Site visits and workshops enabled complementary personal observations as well. In phase three, follow-up sessions with the interview partners confirmed the case study interpretations from the interview data. This triangulation of combining multiple sources of evidence served to confirm the validity and reliability of the research data (Yin, 1994; Voss, Tsikriktsis \& Frohlich, 2002).

\section{Data Analysis}

Data analysis was conducted according to Eisenhardt's approach to building theory from case study research (Eisenhardt, 1989). First, we reflected emerging constructs within the XP case study data with existing theory through data coding (stage 1). In a first step, data were fragmented by open coding, an analytic process by which tentative constructs can be identified and developed in terms of their properties and dimensions. Therefore, observations, sentences, ideas and events were given names and then regrouped into subcategories, which in turn could be grouped as categories. These categories were: (1) financial attractiveness of customers involved in NPD projects, (2) closeness to the customers involved, (3) lead user characteristics of customers involved, (4) NPD planning activities, (5) iterations throughout the NPD process and (6) media employed for visualizing intermediary NPD results (such as simulation equipment and production know-how). In order to avoid differences in coding, there was only one coder. To avoid errors due to subjectivity, the results were discussed with experts on a regular basis. Within each subcategory, if data collected from different sources were inconsistent, we reconciled differences with additional sources of data. In the second step, data were combined in new ways with the objective of regrouping and linking categories with one another in a rational manner. In the final step, core categories were selected and related to other categories. This categorizing led to the identification of the three tentative constructs: (1) access, (2) release and (3) absorption for a reference framework, as well as linkages among the constructs and why such relationships exist (Voss, Tsikriktsis \& Frohlich, 2002) (stage 2). This framework then served as a benchmark for matching the data patterns of the four in-depth case studies, as typical content procedures with analytic induction prescribe (Yin, 1994) (stage 3), leading to four research propositions.

\section{Analysis and Results}

This section presents the findings from our case studies as they relate to our developed reference framework of integrating customer contributions into NPD. The findings are shown along the three constructs customer contribution access, release and absorption. Besides these three, a fourth construct, namely the type of customer contribution, is revealed. The type of customer contribution was identified to be an influencing element for the intensity of the recurring process of accessing, releasing and absorbing customer contributions.

The investigation of the constructs in the context of two in-house developers and two development contractors leads to four propositions.

\section{Access}

\section{Closeness to Customers}

Closeness to customers represents a variable that facilitates interaction between developers and customers. The closeness measures used were the geographical distance between the developer and considered customers and the number of personal contacts between representatives of the developer organization with clients and users throughout the product innovation project. Despite modern communication technology (Gassmann \& von Zedtwitz, 2003), the case study data support the value of close, personal interactions with customers and note the relevance of face-to-face contact, which allows the developer to capture unarticulated customer contributions that can only be observed at the customer site. This supports the work by von Hippel $(1994,1998)$ on sticky information. The following quote points to the 
Table 2. Cross-Case Evidence for Lead User Characteristics

\begin{tabular}{|c|c|c|c|c|}
\hline Characteristics & Hilti & Buechi & IDEO & Tribecraft \\
\hline $\begin{array}{l}\text { Within-industry } \\
\text { focus of users } \\
\text { referred to as } \\
\text { 'lead users' } \\
\text { (or similar with } \\
\text { same meaning) }\end{array}$ & Yes & Yes & No & No \\
\hline $\begin{array}{l}\text { Further user } \\
\text { characteristics } \\
\text { considered }\end{array}$ & $\begin{array}{l}\text { Users within } \\
\text { organizations } \\
\text { which are one } \\
\text { development } \\
\text { cycle ahead and } \\
\text { 'industry average' } \\
\text { (evaluated } \\
\text { through surveys) }\end{array}$ & $\begin{array}{l}\text { Typical users with } \\
\text { positive and } \\
\text { negative attitudes } \\
\text { towards new } \\
\text { concepts }\end{array}$ & $\begin{array}{l}\text { Consideration } \\
\text { of 'extreme' } \\
\text { and 'average' } \\
\text { users }\end{array}$ & $\begin{array}{l}\text { Consideration } \\
\text { of 'professional' } \\
\text { and 'amateur' } \\
\text { users }\end{array}$ \\
\hline
\end{tabular}

relevance of closeness with clients and users by not only product managers, project leaders, and sales representatives but also product engineers and developers.

Also developers participate when we observe focus groups of construction workers testing first functional prototypes. Developers' profound technical comprehension provides valuable insights which could not be understood and absorbed by product managers, even though they also are technically versed. (Project Manager, Hilti)

\section{Lead User Characteristics}

Although the companies studied have their own definition of whom they consider their 'lead users' (see Table 2), we investigate whether von Hippel's lead user characteristics hold true within our case studies. This led to several new findings. The lead user concept (von Hippel, 1976, 1988) postulates that lead users can contribute significantly to product innovations, and that they (1) expect attractive innovation-related benefits from a solution to their needs and so are motivated to innovate, and (2) experience needs for a given innovation earlier than the majority of the target market. While our data supports the first lead user criterion for all companies studied, the application of the second criterion is further discussed.

We found, especially in the cases of the development contractors, that they consciously consider different types of users to cover their different perspectives: IDEO covers the spectrum from 'extreme' to 'average' customers and Tribecraft contacts 'professional' and 'amateur' users - whereas in both cases users can stem from any industry where a similar product application can be observed. Tribecraft also brings them together in workshops to make any differences in practical usage as explicit as possible.

We bring lead users as well as average product users together in meetings and workshops. Such workshops make the differences between the use situations explicit and bring out what is not recognized by individual users, but can represent a big potential for improvements. (Tribecraft founder and partner)

In order to find the best product solution, we not only look for the average user, but also for extreme users. Potential users that we know from other projects or that we identify by analysing different application fields of the concerned product area are contacted by us, and also asked whether they know other individuals who might be even 'more extreme' in their use, to cover the whole spectrum. (Human Factors Specialist, IDEO Germany)

Support for this practice can be found in the fact that users from the 'mass market', which would comprise 'average' and 'amateur' users, face needs at the same time as inventive, or lead users. This finding has also been reported by Lettl, Herstatt and Gemuenden in their study on lead user characteristics in the field of medical technology (Lettl, Herstatt \& Gemuenden, 2006). The difference is that lead 
Table 3. Cross-Case Evidence for Prototyping Practices

\begin{tabular}{lllll}
\hline Characteristics & \multicolumn{1}{c}{ Hilti } & \multicolumn{1}{c}{ Buechi } & IDEO & Tribecraft \\
\hline $\begin{array}{l}\text { Number of physical } \\
\text { visualizations }\end{array}$ & $3-6$ & $2-4$ & More than 15 & $10-15$ \\
$\begin{array}{l}\text { Start of physical } \\
\text { visualizations }\end{array}$ & $\begin{array}{l}\text { After functional } \\
\text { model } \\
\text { development }\end{array}$ & $\begin{array}{l}\text { After functional } \\
\text { model } \\
\text { development }\end{array}$ & $\begin{array}{l}\text { From project } \\
\text { start }\end{array}$ & $\begin{array}{l}\text { From start of } \\
\text { concept phase }\end{array}$ \\
\hline
\end{tabular}

users have the ability to generate their own solutions according to their needs (Lüthje \& Herstatt, 2004), while the same needs representing potential product innovations from 'typical users' need the support of a developer to realize them. We conclude from this fact that besides lead users, the consideration of typical users is necessary to guarantee the compatibility of the product innovation with the practices and values of a lucrative customer segment.

Also the lead user concept proposed by von Hippel (1986) and Urban and von Hippel (1988) recognizes the relevance of not only the lead users, but also of typical users, representative of the broader market segment. Therefore, after innovative product solutions have been generated together with lead users, a concept testing phase follows, where typical users check if they find the lead users' solutions to be appealing. However, our case study data demonstrate the importance of considering typical users not only after collecting input from lead users, but in the same phase, even in the same events - the early involvement of typical users can leverage the lead user contribution by making explicit the innovation potentials that lie in the discrepancies between lead and typical users As a result, more customer know-how that is valuable for the resulting product innovation is released. According to the statements of the development contractors, this practice of also considering typical users does not lower the degree of innovativeness of the product under development.

Thus, a proposition conveying the general expectation concerning the impact of the customers accessed throughout the product innovation process may be stated as follows:

Proposition 1: Continuous consideration of lead users as well as typical users throughout the product innovation process results in superior customer contribution access.

\section{Release}

The reference framework developed from the existing literature indicated the relevance of visualizing intermediary product innovation results through working models, or early prototypes for the integration of customers. To measure the degree to which the companies studied employed intermediary result visualization in their communication with the customer, a look at the number of physical visualizations (which also can be very simple and approximate prototypes) has been analysed. In addition, the timing of physical visualizations in the NPD process was investigated. Table 3 lists these visualization practices for the four cases.

Table 3 shows that Buechi and Hilti present functional prototypes to the customer at a relatively late stage. As a consequence, only a few prototypes are built, but they comprise design as well as functionality aspects in one device.

If a concept or prototype presented to customers is poorly conceived as regards look and feel, customers usually decline a new product. Therefore, design and interfaces have to be at an appealing level for user visits. (Head Business Unit Research \& Discovery, Buechi)

In contrast to the prototyping practice of the in-house developers, IDEO and Tribecraft apply techniques to focus customers on single aspects of product modules, where specific problems have to be solved and client decisions are required. This holds true for functional as well as design issues which are elaborated separately. IDEO builds several prototypes for every single module, for example, while a first prototype aims at simulating the product's stability, a second one simulates only the nature of the surface, and a third prototype is built only to simulate the future module's weight.

Already in the idea phase, we observe the relevant stakeholders in their environment, visualize what we find, and build rough prototypes, which we discuss with the client. These prototypes build the basis to realize the next project step. (Tribecraft founder and partner) 
Every prototype is built for one specific purpose - not to simulate the entire new product which will be built. The prototype has to fully concentrate on this aspect as to avoid confusions regarding other aspects. (Product developer, IDEO Germany)

Taken together, the case study data support the relevance of a differentiated consideration of customer contribution release, meaning to make customer's implicit and explicit knowhow available for developers. The value of demonstrating to customers multiple and highly modular prototypes from a very early stage in the NPD process includes identifying possible problems and preferences for the future product.

The impact of the multiple and modular prototyping practice on the release of customer contributions may be stated formally as follows:

Proposition 2: Application or inclusion of multiple and modular visualizations of (intermediate) innovation project results will have a positive effect on customer contribution release.

\section{Absorption}

In the reference framework we proposed that the absorption capability of customer contributions depends on the planning flexibility of the NPD process. The measure for process flexibility used was the amount of NPD process formalization, further specified by project planning, project specification freeze and the deciding authority over customer contribution implementation. Table 4 lists the planning flexibility measures for the four cases.

Process formalization of Hilti and Buechi is high and therefore project planning more rigorous, compared to the development contractors.

Product innovations at Buechi start with a strategy and vision, which is formulated for every business unit. The product innovation process includes six phases: (1) idea generation, (2) market and technical analysis, (3) functional model development, (4) prototype development, (5) pilot production, and (6) market introduction. We conduct a phase review after every development phase. (Head Business Unit Research \& Discovery, Buechi)

IDEO and Tribecraft have a low formalized NPD process, with process steps serving more as a guideline than imposing rigour to the project procedure: a new product evolves along an interactive process between developer, client and users.

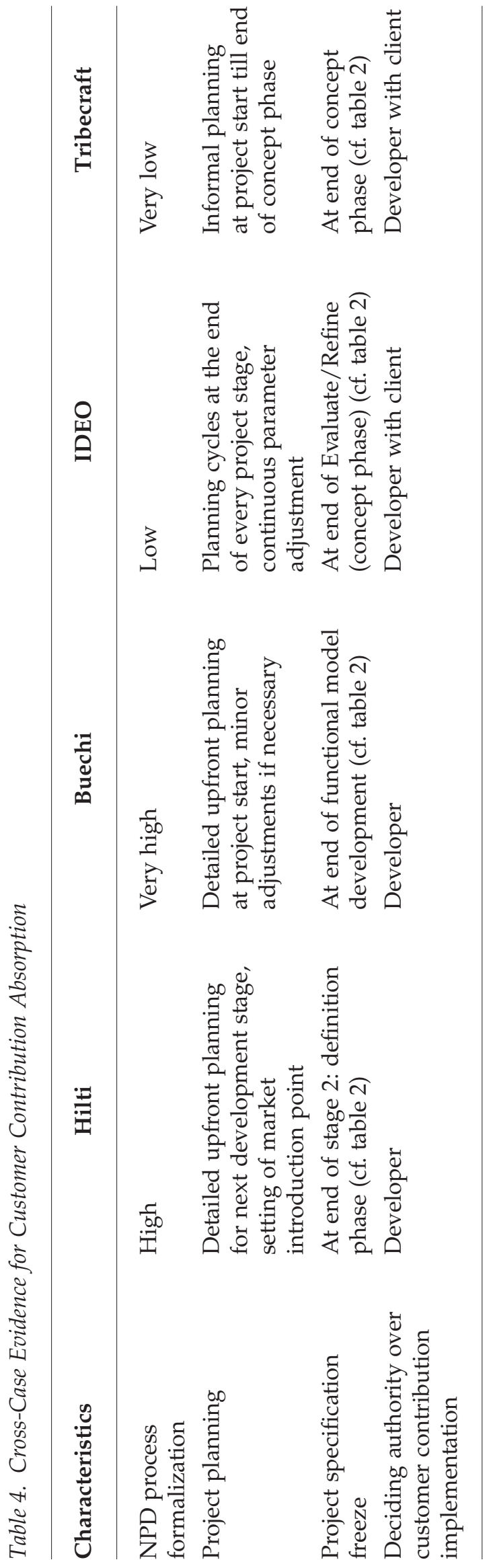


Our design methodology has the following steps: understand, visualize, evaluate, and implement. Some steps are iterated many times in a single project and 'aerated' through brainstorming sessions with the entire crew. (Manager IDEO Germany)

IDEO's and Tribecraft's project planning is informal, focusing on the sequencing development cycle and being continually adjusted. The consequence of this practice at IDEO and Tribecraft is a very strong focus on those product functions and features which matter most to clients and users. This practice can also be observed at the in-house developers; however, while IDEO and Tribecraft involve clients and users in the prioritization of product features and functions initially at the idea stage, Buechi does not apply function and feature prioritization until the early concept stage, and Hilti only in the late concept stage and then solely to adjust design and handling aspects.

To assure the customers' product acceptance and willingness to buy the completely new fastening concept, we present functioning prototypes to selected customers in the concept stage. Product users test the prototypes on the construction sites and provide feedback about the prototype's functionalities. (Project Manager Business Area Direct Fastening, Hilti)

Although Hilti considers its clients for feature prioritization only at a late stage, it practises iterative product planning within its formalized stage-gate process. While the rough project parameters are set at project start, detailed planning is carried out at a gate only for the sequencing development stage, but not for the whole project.

Taken together, the separate focus on customer contribution absorption leads to the following proposition:

Proposition 3: Superior customer contribution absorption throughout the product innovation process will induce iterative instead of up-front innovation project planning.

\section{Type of Customer Contribution}

The case studies identified two major categories of contributions. First, major contributions in terms of determining new product scope and functionalities, and second, minor contributions in terms of verifying the product relevance and feedback for design and handling adjustments. An overview of these customer contributions, as well as the customers specific involvement within the cases studied, is shown in Table 5.

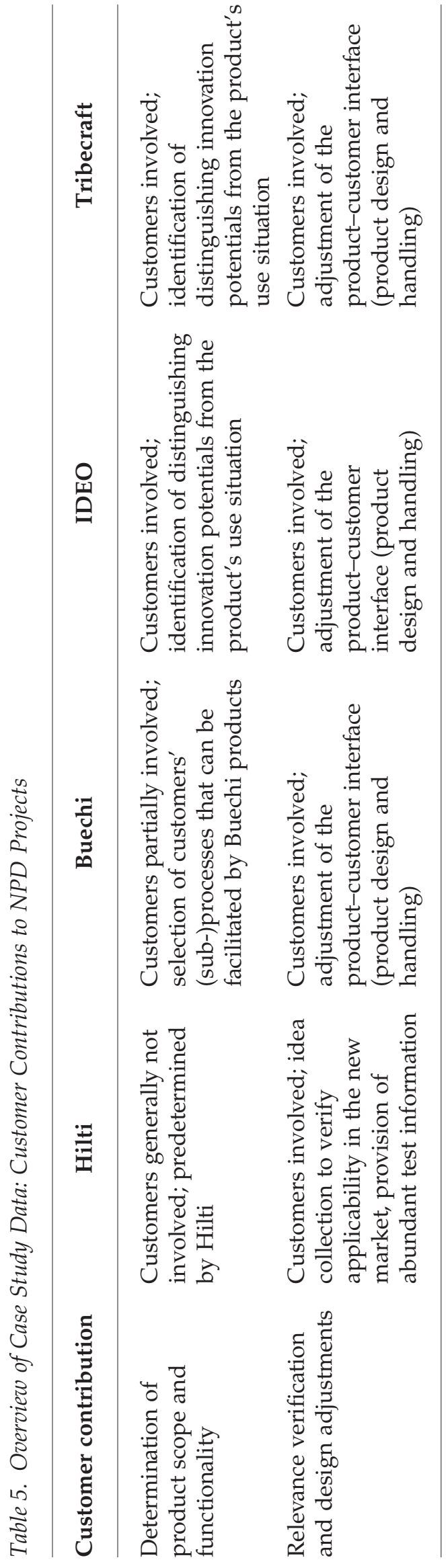


Table 6. Customer Integration: Comparison between In-house Developers and Development Contractors

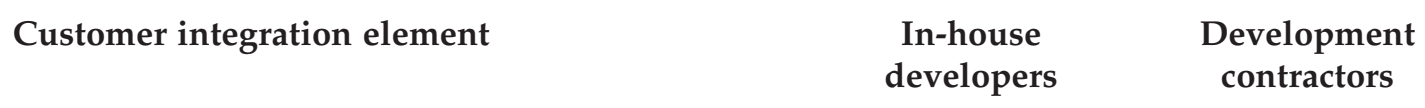

Access: Leading and typical user consideration Release: Visualization of intermediate project results Absorption: Project planning Customer contribution type: Industry competence

Occasional
Integral
Up-front
High

Continual

Multiple and modular Predominantly iterative Low products, and services for professional customers in the construction industry and building maintenance and therefore we can sell our products at a price which is 20 up to $40 \%$ above competitors' prices. (Project Manager Business Area Direct Fastening, Hilti)

Following from the above we state a fourth proposition.

Proposition 4: The industry competence of the developer constitutes the customer contribution type and impacts the intensity of contribution access, release and absorption.

\section{Summary}

Based on our reference framework, we compared the product innovation practices of two in-house developers with two development contractors. We included development contractors in our study as their resulting new products are on average seen as more innovative - this is what the development contractor's business model promises. The comparison led us to four propositions which are summarized in Table 6.

Since the development contractors have only limited competences in-house for a specific NPD project, they connect industry specialists as well as clients and users in their development activities. As a consequence, the products IDEO and Tribecraft introduce are less dominated by the perspective of one developing company, but more open to bring together different technological possibilities and market needs. Accessing, releasing and absorbing customer contributions thus takes place in many more cycles than in the NPD practice of in-house developers.

\section{Discussion}

The integration of customer contributions in NPD has many benefits: it leads to a higher degree of product newness, reduced innova- 
tion risks and more precision in resource spending (Kohli \& Jaworski, 1990; Bacon et al., 1994; Brockhoff, 2003; Callahan \& Lasry, 2004). Our analysis indicates that the iterative incorporation of customers' contribution into the product development process enables a faster and more efficient reaction to market changes and the discovery of new product innovation potentials. The findings suggest that the method of continuous integration of customer contributions leads to an increased likelihood of improved project profitability through continuous guidance of the development process by customer requirements and through relevance checks, and therefore to more satisfied customers. In the companies studied, the achievable advantages exceed the costs arising from the provision of multiple iterations and prototypes, and the number of development projects that lead to failures in the market can be reduced significantly.

In this study, a reference framework was developed with the help of the XP method from software engineering as an underlying metaphor for extreme customer know-how integration. It led to the introduction of the constructs customer contribution access, release, absorption and type. These constructs may be regarded as building blocks for a product innovation approach which responds to fast changing customer requirements and 'moving development targets'. With the reference framework, the practices of in-house developers were compared with those of development contractors in order to gain deeper insights, formally stated in four propositions.

Although our study is descriptive rather than normative in nature, we can make tentative statements of how our observations can guide managerial action. Specific observations can be drawn at the following levels.

First, while existing research has addressed the access of customers and their contributions in product innovation (Gruner \& Homburg, 2000), it has not explicitly differentiated access, release and absorption of customer contributions. The differentiated consideration of these aspects in practice can make customer integration measures more effective.

Second, investigating the application of the lead user method in the NPD process (von Hippel, 1986, 1988), our study supports the valuable contribution it makes to product innovations. However, we found that the early involvement of typical users at a very early stage can leverage the contribution from lead users by making explicit the innovation potentials that lie in the discrepancies between lead and typical users - this without lowering the innovativeness of the new product under development.
Third, the case studies demonstrated the value of multiple modular prototypes as well as an iterative NPD planning approach, starting with the product attributes which matter most to clients and users and evolving through continuous evaluation of further functions and features by customers, thus providing incremental guidance. However, an aspect which needs further investigation in this context is the cost-benefit ratio of multiple and expensive prototype production of partitioned tasks, as is the case, for example, in heavy industries.

The comparison demonstrated that NPD and customer integration practices of the in-house developers significantly vary from those of the development contractors. The analysis revealed that the in-house developers do adopt $\mathrm{XP}$-near practices, but in a piecemeal manner. The NPD process structure of the development contractors, by contrast, shows close similarities to the overall XP process. Due to less formalization and extensive prototyping practices, it has superior customer contribution release and absorption possibilities, and generally yields product innovations with a higher degree of newness. Furthermore, the development contractors' independence compared to established market players' competitive situation provides the contractors with a broad access to the various specialists in the market.

Finally, our study highlights the relevance of directing the NPD process structure towards 'discrete' sequencing development steps, evolving through the continuous integration of customer contributions. These discrete steps, employing extensive visualization and prototyping techniques, represent a solution to overcome the difficulties of transferring knowledge from customers to the developer (von Hippel, 1994, 1998). Discreteness refers to the characteristic that every development step leads to an intermediary project result, e.g., in the form of a prototype or visualization which can be presented to customers to collect new input. Where projects have a high product requirement uncertainty, an innovation process according to the $\mathrm{XP}$ principles enables a company to respond in a flexible manner to new opportunities discovered throughout the project itself by the intense interaction with the customer.

\section{Limitations of the Study and Implications for Further Research}

There are several limitations to our study. By choosing to focus on a limited set of industrial NPD, the results by necessity do not consider NPD projects with other characteristics. The 
fact that only two in-house developers and two development contractors were investigated represents a major limitation, but helped to analyse opposing ends of the spectrum for this research project. Due to the limited space for presenting our work, the qualitative data shown needed to be radically summarized which undermines some of the traditional richness associated with case-based research. The results can be applied to other firms with similar innovation processes; however, extensions to other industries must be made carefully. In particular, industries with highly regulated innovation processes, such as the FDI-driven pharmaceutical industry or sequential process industries such as the chemical industry, might have more limitations in adapting the results of our research. An area for future research is the replication of the study in other industry settings, for example in consumer goods, which pose a different problem from industrial goods.

Furthermore, our analysis has been restricted to a Northern European context. Although in the design of the study no aspects were incorporated that are specific to Northern Europe, an international replication study could yield interesting results.

The research scope of this study opens a wide area for additional research. Based on our comparison of in-house developers and development contractors, an investigation aspect might be how development contractors can best assist customer integration in product innovation on behalf of in-house development departments.

An empirical study is advised in order to test the hypotheses. The field of customer integration in the early $R \& D$ process is receiving heightened attention from academics as well as from practitioners.

\section{References}

Acebal, C.F. and Cueva Lovelle, J.M. (2002) A New Method of Software Development: Extreme Programming. Informatik, 2, 5-9.

Adams, M.E., Day, G.S. and Dougherty, D. (1998) Enhancing New Product Development Performance: An Organizational Learning Perspective. Journal of Product Innovation Management, 15, 40322.

Albers, S. and Eggers, S. (1991) Organisatorische Gestaltungen von Produktinno-vationsProzessen. Führt der Wechsel des Organisationsgrades zu Innovationserfolg? Zeitschrift der Betriebswirtschaftlichen Forschung (zfbf), 43, 44-64.

Allen, T.J. (1977) Managing the Flow of Technology. MIT Press, Cambridge, MA.

Anderson, J.C. and Narus, J.A. (1990) A Model of Distributor Firm and Manufacturer Firm Working Partnerships. Journal of Marketing, 54, 42-58.
Atuahene-Gima, K. (1996) Market Orientation and Innovation. Journal of Product Innovation Management, 13, 456-7.

Bacon, G., Beckman, S., Mowery, D. and Wilson, E. (1994) Managing Product Definition in HighTechnology Industries: A Pilot Study. California Management Review, 36, 32-56.

Berry, L.L. and Parasuraman, A. (1997) Listening to the Customer - the Concept of a Service-Quality Information System. MIT Sloan Management Review, 38, 65-76.

Biemans, W.G. (1992) Managing Innovation within Networks. Routledge, London.

Billington, J. (1998) Customer-Driven Innovation. Harvard Management Update, 3, 1-3.

Boehm, B., Gray, T. and Seewaldt, T. (1984) Prototyping versus Specifying: A Multiproject Experiment. IEEE Transactions on Software Engineering, 10, 290-303.

Brockhoff, K. (2003) Customers' Perspectives of Involvement in New Product Development. International Journal of Technology Management, 26, 464-81.

Buttle, F. (1996) Relationship Marketing: Theory and Practice. Sage Publications, London.

Callahan, J. and Lasry, E. (2004) The Importance of Customer Input in the Development of Very New Products. RED Management, 34, 107-20.

Chesbrough, H.W. (2003) Open Innovation: The New Imperative for Creating and Profiting from Technology. Harvard Business School Press, Boston, MA.

Cooper, R.G. (1990) Stage-Gate Systems: A New Tool for Managing New Products. Business Horizons, 33, 44-54.

Cooper, R.G. (1994) Perspective Third-Generation New Product Processes. Journal of Product Innovation Management, 11, 3-14.

Cooper, R.G. (2001) Winning at New Products: Accelerating the Process from Idea to Launch. Perseus Publishing, Reading, MA.

Cooper, R.G. and Kleinschmidt, E.J. (1986) An Investigation into the New Product Process: Steps, Deficiencies, and Impact. Journal of Product Innovation Management, 3, 71-85.

Dahan, E. and Hauser, J.R. (2002) The Virtual Customer. Journal of Product Innovation Management, 19, 332-53.

Doney, P.M. and Cannon, J.P. (1997) An Examination of the Nature of Trust in BuyerSeller Relationships. Journal of Marketing, 61, 35-51.

Dornberger, R. and Habegger, T. (2004) Extreme Programming - Eine Übersicht und Bewertung. Reihe A: Discussion Paper 2004-05, 1-51.

Eisenhardt, K.M. (1989) Building Theories from Case Study Research. Academy of Management Review, 14, 532-50.

Eisenhardt, K.M. and Tabrizi, B.N. (1995) Accelerating Adaptive Processes: Product Innovation in the Global Computer Industry. Administrative Science Quarterly, 40, 84-110.

Fiol, C.M. and Lyles, M.A. (1985) Organizational Learning. Academy of Management Review, 10, 803-13.

Ganesan, S. (1994) Determinants of Long-Term Orientation in Buyer-Seller Relationships. Journal of Marketing, 58, 1-19. 
Gassmann, O. (2006) Opening up the Innovation Process: Towards an Agenda. RED Management, 36, 223-8.

Gassmann, O. and Enkel, E. (2004) Towards a Theory of Open Innovation: Three Core Process Archetypes. Proceedings of the RED Management Conference (RADMA), Lisbon, Portugal, RED Management, July 6-9.

Gassmann, O. and von Zedtwitz, M. (2003) Trends and Determinants of Managing Virtual R\&D Teams. RED Management, 33, 243.

Griffin, A. and Hauser, J.R. (1993) The Voice of the Customer. Marketing Science, 12, 1-27.

Griffin, A. and Page, A.L. (1996) PDMA Success Measurement Project: Recommended Measures for Product Development Success and Failure. Journal of Product Innovation Management, 13, 47896.

Gruner, K.E. and Homburg, C. (2000) Does Customer Interaction Enhance New Product Success? Journal of Business Research, 49, 1-14.

Gupta, A.K., Raj, S.P. and Wilemon, D. (1986) A Model for Studying R\&D - Marketing Interface in the Product Innovation Process. Journal of Marketing, 50, 7-17.

Herstatt, C. and Von Hippel, E. (1992) From Experience: Developing New Product Concepts Via the Lead User Method: A Case Study in a 'LowTech' Field. Journal of Product Innovation Management, 9, 213-21.

Huber, G.P. (1991) Organizational Learning: The Contributing Processes and the Literatures. Organization Science, 2, 88-115.

Hutt, M.D. and Stafford, E.R. (2000) Defining the Social Network of a Strategic Alliance. MIT Sloan Management Review, 41, 51-62.

Iansiti, M. (1998) Technology Integration: Making Critical Choices in A Dynamic World. Harvard Business Press, Boston, MA.

Imai, K., Ikujiro, N. and Takeuchi, H. (1985) Managing the New Product Development Process: How Japanese Companies Learn and Unlearn. In Hayes, R.H., Clark, K. and Lorenz, C. (eds.), The Uneasy Alliance: Managing the Productivity-Technology Dilemma. Harvard Business School Press, Boston, MA, 33775.

Jeppesen, L.B. and Molin, M.J. (2003) Consumers as Co-Developers: Learning and Innovation outside the Firm. Technology Analysis \& Strategic Management, 15, 363-83.

Kaulio, M.A. (1998) Customer, Consumer and User Involvement in Product Development: A Framework and a Review of Selected Methods. Total Quality Management, 9, 141-9.

Kim, J. and Wilemon, D. (2002) Focusing the Fuzzy Front-End in New Product Development. RED Management, 32, 269-79.

Kohli, A.K. and Jaworski, B.J. (1990) Market Orientation: The Construct, Research Propositions, and Managerial Implications. Journal of Marketing, 54, $1-17$.

Kok, R.A.W., Hillebrand, B. and Biemans, W.G. (2003) What Makes Product Development Market Oriented? Towards a Conceptual Framework. International Journal of Innovation Management, 7, 137-62.
Lettl, C., Herstatt, C. and Gemuenden, H.G. (2006) Learning from Users for Radical Innovation. International Journal of Technology Management, 33, $25-45$.

Lilien, G.L., Morrison, P.D., Searls, K., Sonnack, M. and Von Hippel, E. (2002) Performance Assessment of the Lead User Idea-Generation Process for New Product Development. Management Science, 48, 1042-59.

Lüthje, C. and Herstatt, C. (2004) The Lead User Method: An Outline of Empirical Findings and Issues for Future Research. RED Management, 34, 553-68.

Lüthje, C., Herstatt, C. and von Hippel, E. (2005) User-Innovators and 'Local' Information: The Case of Mountain Biking. Research Policy, 34, 951-65.

Lynn, G.S., Morone, J.G. and Paulson, A.S. (1996) Marketing and Discontinuous Innovation: The Probe and Learn Process. California Management Review, 38, 8-37.

MacCormack, A., Verganti, R. and Iansiti, M. (2001) Developing Products on 'Internet Time': The Anatomy of a Flexible Development Process. Management Science, 47, 133-50.

March, J.G. (1991) Exploration and Exploitation in Organizational Learning. Organization Science, 2, 71-87.

Martin, A., Noble, J. and Biddle, R. (2003) Being Jane Malkovich: A Look into the World of an XP Customer. Fourth International Conference on eXtreme Programming and Agile Processes in Software Engineering, Genova (Italy), Lecture Notes in Computer Science 2675, Springer.

Martin, A., Biddle, R. and Noble, J. (2004) The XP Customer Role in Practice: Three Studies. Advanced Developers Conference (ADC), Salt Lake City.

Menon, A. and Varadarajan, P.R. (1992) A Model of Marketing Knowledge Use within Firms. Journal of Marketing, 56, 53-71.

Millson, M.R. and Wilemon, D. (2002) The Impact of Organizational Integration and Product Development Proficiency on New Product Success. Industrial Marketing Management, 31, 1-23.

Morgan, R.M. and Hunt, S.D. (1994) The Commitment-Trust Theory of Relationship Marketing. Journal of Marketing, 58, 20-38.

Morrison, P.D., Roberts, J.H. and Midgley, D.F. (2004) The Nature of Lead Users and Measurement of Leading Edge Status. Research Policy, 33, 351-62.

Mullins, J.W. and Sutherland, D.J. (1998) New Product Development in Rapidly Changing Markets: An Exploratory Study. Journal of Product Innovation Management, 15, 224-36.

Murphy, S.A. and Kumar, V. (1997) The Front End of New Product Development: A Canadian Survey. RED Management, 27, 5-15.

Myers, S. and Marquis, D.G. (1969) Successful Industrial Innovations. National Science Foundation, Washington, DC.

Paustian, C. (2001) Better Products through Virtual Customers. MIT Sloan Management Review, 42, $1-2$.

Punch, K.F. (1998) Introduction to Social Research: Quantitative and Qualitative Approaches. Sage Publications, London. 
Quinn, J. B. (1985) Managing Innovation: Controlled Chaos. Harvard Business Review, 63, 73-84.

Rindfleisch, A. and Moorman, C. (2001) The Acquisition and Utilization of Information in New Product Alliances: A Strength-of-Ties Perspective. Journal of Marketing, 65, 1-18.

Simon, H.A. (1969) The Sciences of the Artificial. MIT Press, Cambridge, MA.

Simonson, I. (1993) Get Closer to Your Customers by Understanding How They Make Choices. California Management Review, 35, 68-84.

Stake, R.E. (1988) Case Study Methods in Educational Research: Seeking Sweet Water. In Jaeger, R. (ed.), Complementary Methods for Research in Education. American Educational Research Association, Washington DC, 253-300.

Terwiesch, C. and Loch, C.H. (2004) Collaborative Prototyping and the Pricing of Custom-Designed Products. Management Science, 50, 145-58.

Thomke, S.H. (1998) Managing Experimentation in the Design of New Products. Management Science, 44, 743-62.

Thomke, S.H. (2001) Enlightened Experimentation. The New Imperative for Innovation. Harvard Business Review, 79, 67-76.

Urban, G.L. and Von Hippel, E. (1988) Lead User Analyses for the Development of New Industrial Products. Management Science, 34, 569-82.

Veryzer, R.W. and Borja De Mozota, B. (2005) The Impact of User-Oriented Design on New Product Development: An Examination of Fundamental Relationships. Journal of Product Innovation Management, 22, 128-43.

Von Hippel, E. (1976) The Dominant Role of Users in the Scientific Instrument Innovation Process. Research Policy, 5, 212-39.

von Hippel, E. (1977) Transferring Process Equipment Innovations from User-Innovators to Equipment Manufacturing Firms. RED Management, 8, 13-22.

Von Hippel, E. (1978) Successful Industrial Products from Customer Ideas. Journal of Marketing, 42, 39-49.

Von Hippel, E. (1986) Lead Users: A Source of Novel Product Concepts. Management Science, 32, 791805.

Von Hippel, E. (1988) The Sources of Innovation. Oxford University Press, New York.

Von Hippel, E. (1994) Sticky Information and the Locus of Problem Solving: Implications for Innovation. Management Science, 40, 429-39.

Von Hippel, E. (1998) Economics of Product Development by Users: The Impact of 'Sticky' Local Information. Management Science, 44, 629-44.

Von Hippel, E. and Katz, R. (2002) Shifting Innovation to Users Via Toolkits. Management Science, 48, 821-33.
Voss, C., Tsikriktsis, N. and Frohlich, M. (2002) Case Research in Operations Management. International Journal of Operations and Production Management, 22, 195-219.

Wheelwright, S.C. and Clark, K.B. (1992) Revolutionizing Product Development - Quantum Leaps in Speed, Efficiency and Quality. The Free Press, New York.

Wilson, J.Q. (1966) Innovations in Organizations: Notes Toward A Theory. Approaches to Organizational Design. In Thompson, J.D. (ed.) University of Pittsburgh Press, Pittsburgh.

Yin, R.K. (1994) Case Study Research: Design and Methods. Sage Publications, Thousand Oaks, CA.

Zahay, D., Griffin, A. and Fredericks, E. (2004) Sources, Uses, and Forms of Data in the New Product Development Process. Industrial Marketing Management, 33, 657-66.

Patricia Sandmeier (patricia.sandmeier@ ch.abb.com) works for ABB, Switzerland, responsible for business development of the domestic market. She earned a PhD from the Department of Technology Management, University of St Gallen (Switzerland) and was a visiting researcher at the University of New South Wales, Sydney (Australia) and at the University of California, Berkeley (USA). Her research interests include customer integration strategies in new product development and process management in open innovation projects.

Pamela Morrison (pamm@unsw.edu.au) is Professor of Marketing at the University of New South Wales, Australia. Her research areas are diffusion of innovations, new product development, co-branding/ alliances and high technology marketing.

Oliver Gassmann (oliver.gassmann@ unisg.ch) is Professor of Technology Management at the University of St Gallen, Switzerland and Director of the Institute of Technology Management. He has published in leading journals such as Journal of Management, Research Policy, MIR, RED Management, and Journal of World Business. In 2009 he was awarded as one of the Top 50 researchers worldwide by IAMOT in Orlando. At the core of his research is the pervading question of how companies innovate and profit from innovation. 